http://dx.doi.org/10.18778/2080-8313.15.02

\author{
Jarosław Kita \\ (University of Łódź, \\ Faculty of Philosophy and History)
}

\title{
BANKS IN ŁÓDŹ AND THEIR PRE-1918 ACTIVITIES
}

S

tereotypically, $19^{\text {th }}$-century Łódź is depicted as a city of enormous factories, mainly textile; ornamented palaces and villas of manufacturers and with ever-present traces of Art Nouveau. In the late $19^{\text {th }}$ century it was the second most densely populated town in the Kingdom of Poland and the fifth in the whole Russian Empire ${ }^{1}$. The development of Łódź was atypical of a contemporary city since it was of unidirectional character, based on industrial monoculture.

In a flash, urban space filled with factories and newly acquired wealth. In the city, the main power was money and income. In the mid 1860s, Adam Wiślicki, a well-known Warsaw journalist, wrote in one of his articles published in the illustrated weekly magazine „Kłosy”, making use of the description of Łódź from „Warschauer Zeitung”:

Now we would like to focus public attention on the present growth of the city of Łódź; this small settlement devoid of any souvenirs of yesterday, precious works of art, impressive constructions apart from enormous factories, where the cotton thread is woven six days a week in a mundane pace, in the very same way time flies in that populated, yet socially empty town ${ }^{2}$.

An industrial city, in which rotating capital and collecting profits was of paramount importance, could not function without its financial and credit institutions, the banks especially. They enabled business trade and gaining credits and short and long-term loans. Such ascertainment concerns the great industrial city, into which Łódź gradually transformed in the late $1860 \mathrm{~s}^{3}$

\footnotetext{
${ }^{1}$ According to the census of 1897 after Petersburg (1 264 920), Moscow (1 038 591), Warsaw (638 692) and Odessa (403 815) with the population (314 000). In: L. Bazylow, Historia Rosji, t. II, Warszawa 1983, s. 323.

${ }^{2}$ A. Wiślicki, Obecny wzrost miasta Łodzi, „Kłosy” 1865, nr 10; 1865, nr 11. Trans. by author.

${ }^{3}$ More details are given in: J. Kita, Rozwój gospodarczy i spoleczny Łodzi w XIX-XX wieku (do 1945 r.), [w:] Rola nauczycieli tódzkich w tworzeniu dziedzictwa kulturowego Łodzi, red. S. Gala, Łódź 1998, s. 29-44.
} 
During the first phase of the city's industrial career, the craftsmen and entrepreneurs coming there applied for loans from the Bank of Poland (with the support of Masovian Voivodeship Committee - Warsaw Governorate and Masovian Governorate Governments) and the Governmental Committee of Internal Affairs; invested their own possessions or used individually acquired loans.

Between 1819 and 1865, German industrialists from the areas forming Lódź industrial district gained over 5,5 mln credits from the government and the Bank of Poland. Owing to that, the greatest companies of the the Geyers ${ }^{4}$, the Grohmans and the Scheiblers ${ }^{5}$ were established. During several decades in Łódź there existed no bank or any other financial and credit institution. The situation changed just before the January Uprising.

During the next fifty years, until the outbreak of World War I, plenty of modern financial institutions were established here due to a rapid development of Łódź and its satellite cities. Among them there were banks, branches of banks that had their headquarters in other cities, bank houses, but also Urban Credit Society, savings and loan companies and mutual credit companies. In 1870 in Łódź there were only two institutions of this kind, whereas at the outbreak of WWI, in 1913 the number of them was 37. Is should be mentioned, however, that banks comprised only 20 per cent of them, since there existed only 7 of them (see Table 1).

The appearance of these institutions was a natural consequence of the outburst of the city's prosperity since Łódź turned into a magnificent industrial and commercial centre. In the next phase, having their finances secured, the institutions eagerly triggered the evolution of local infrastructure as well. In the article I will focus on the depiction of the appearance, activities and growth of the banks, bank branches and the biggest bank houses, business trade of which often exceeded that of many banks of the whole Kingdom of Poland, and sometimes even Russian Empire.

In 1858, a decision to establish a branch of the Bank of Poland, the main role of which was to support the economic policy of the Kingdom of Poland, was issued $^{6}$. Its activity was of limited character though, since the branch resembled a storehouse which was given permission to offer loans on pledge of such goods as cotton, wools, blanks, final products, dyeing materials, meal sugar and refined

\footnotetext{
${ }^{4}$ In 1860 the company of L. Geyer owed over 4 mln złp to State Treasury in The Bank of Poland.

${ }^{5}$ In G. Missalowa, Studia nad powstaniem łódzkiego okręgu przemystowego 1815-1870, t. 3: Burżuazja, Łódź 1975, s. 29-97; K. Woźniak, Źródła finansowania przemystu włókienniczego w okręgu łódzkim do lat pięćdziesiątych XIX w., „Roczniki Dziejów Społeczno-Gospodarczych”, t. 49, 1988, s. 39-64; W. Puś, Rozwój przemystu w Królestwie Polskim 1870-1914, Łódź 1997, s. 17-18.

${ }^{6}$ It needs to be stressed that the first financial institution founded in Łódź was Lódzka Kasa Oszczędnościowa, established in 1851. However, due to small capital it was of minor importance in the development of the city's economy. In: Archiwum Państwowe w Łodzi (dalej: APŁ), Akta miasta Łodzi (dalej: AmŁ), sygn. 145; F. Friedman, Rozwój gospodarczy Łodzi do roku 1914, „Ekonomista" 1938, t. I, s. 96.
} 
The development of financial and credit institutions in Łódź in the years 1870-1913

\begin{tabular}{|c|c|c|c|c|c|c|c|}
\hline Year & Banks & $\begin{array}{c}\text { Bank bran- } \\
\text { ches (the } \\
\text { branches } \\
\text { of the Bank } \\
\text { of Poland } \\
\text { included) }\end{array}$ & $\begin{array}{c}\text { Bank } \\
\text { houses }\end{array}$ & $\begin{array}{c}\text { Urban } \\
\text { Credit } \\
\text { Society }\end{array}$ & $\begin{array}{c}\text { Mutual } \\
\text { credit } \\
\text { companies }\end{array}$ & $\begin{array}{c}\text { Savings } \\
\text { and loan } \\
\text { companies }\end{array}$ & All \\
\hline 1870 & - & 1 & 1 & - & - & - & 2 \\
\hline 1887 & 1 & 1 & 5 & 1 & 1 & - & 9 \\
\hline 1894 & 1 & 2 & 7 & 1 & 1 & - & 12 \\
\hline 1902 & 2 & 4 & 11 & 1 & 2 & 2 & 22 \\
\hline 1904 & 2 & 4 & 11 & 1 & 2 & 3 & 23 \\
\hline 1908 & 2 & 5 & 3 & 1 & 4 & 4 & 19 \\
\hline 1910 & 2 & 5 & 3 & 1 & 7 & 6 & 24 \\
\hline 1911 & 2 & 5 & 3 & 1 & 7 & 9 & 27 \\
\hline 1912 & 2 & 5 & 3 & 1 & 9 & 12 & 32 \\
\hline 1913 & 2 & 5 & 3 & 1 & 9 & 17 & 37 \\
\hline
\end{tabular}

Source: „Czas”. Kalendarz na lata 1900, 1902, 1904, 1908-1913; „Łodzianin”. Kalendarz informacyjno-adresowy na rok 1894, Łódź 1893, Dział adresowy, s. 12; Führer durch Lodz, Lodz 1898, Allgemeine Adressen, s. 6-7; K. Badziak, Instytucje finansowo-kredytowe w Lodzi do I wojny światowej, „Rocznik Łódzki”, t. 22 (25), 1977, s. 107.

sugar? The storehouse of the Bank of Poland in Łódź was governed by Teofil Rzuchowski ${ }^{8}$, aided by Advisory Commitee, with the former President of Łódź, Franciszek Traeger, as its chair. Among other members, there were: industrialist Karol Scheibler, the owner of colonial goods storehouse, K. Gehlig and entrepreneur, Juliusz Wergau. In February 1860, the Bank of Poland Council bought a property in 268 Piotrkowska Street, close to Górny Rynek, with a building erected, from Ludwik Geyer and it became the first head office of its branch in Łódź. The construction exists today, but the form of it has been slightly changed ${ }^{9}$. In the

${ }^{7}$ H. Radziszewski, Bank Polski, wyd. II, Poznań 1919, s. 286-287.

${ }^{8}$ Archiwum Główne Akt Dawnych, Inwentarz zespołu Bank Polski 1828-1885; Bank Polski 1828-1885, sygn. 137, k. 127, 305-306. In 1850 he was nominated a first rank clerk in the Bank of Poland.

${ }^{9}$ APŁ, AmŁ, sygn. 6; A. Rynkowska, Ulica Piotrkowska, Łódź 1970, s. 113. 
initial phase of the January Uprising, during the night from January 31 to February 1,1863 , a group of insurgents attacked the branch headquarters and stole over $18000 \mathrm{rb}^{10}$

After the fall of the Uprising, the activities of the branch of the Bank of Poland were not so dynamic any more. The relation between the branch of the Bank of Poland in Łódź and local entrepreneurs meant mainly short-term credits (based on negotiable arguments) and offering loans on the pledge of valuable objects.

Granting a long-term loan was hardly possible, especially after 1870 , when industrial companies were excluded from the group able to acquire it ${ }^{11}$. In the mid 1870 s, the head office of the branch was moved to a tenement house on the corner of Ceglana Street (now Więckowskiego Street) and 55 Zachodnia Street $^{12}$. In 1885 the Bank of Poland was dissolved due to unification policy of the Russian Empire, and became a part of Russian National Bank (which was founded in 1860). In that way, the branch of the Bank of Poland in Łódź was transformed into an agency of Russian National Bank. Until its dissolvement (or transformation), it had discounted promissory notes of $66,2 \mathrm{mln} \mathrm{rb}$. value ${ }^{13}$.

After 1885, the branch of the National Bank of Poland in Łódź still represented the economic policy of the invaders that tried hard to limit the financial activities in the Kingdom of Poland. Documents prove that until 1913 only 392 credits were given, comprising $27,3 \mathrm{mln} \mathrm{rb}$. Those who were permitted to acquire them were usually enormous industrial companies that possessed sufficient financial basis, for instance Towarzystwo Akcyjne Allarta and Rousseau (1911 - 600000 rb.), Towarzystwo K. Steinerta (1911 - 500000 rb.), Towarzystwo Akcyjne S. Rosenblatta $(1911-200000 \mathrm{rb} .)^{14}$.

In Łódź, the branch of the Bank of Poland paid a crucial role in discounting promissory notes and short-term credits. In 1898 the branch discounted promissory notes of $45,7 \mathrm{mln} \mathrm{rb}$. value, whereas a privately owned Commercial Bank (Bank Handlowy) in 1896 discounted the notes of a much smaller 19,3 mln rb. value (1896). Moreover, the agency of the National Bank, as a central institution, was entitled to store warranty documents of financial and credit institutions of Łódź. On its accounts, there were financial resources of the majority of enterprises and trading companies kept.

${ }^{10}$ A. Barszczewska, Nurty walki. Udział Łodzi i okręgu tódzkiego w ruchach narodowowyzwoleńczych 1795-1864, Łódź 1971, s. 252; Łódź. Dzieje miasta, red. R. Rosin, t. I: Do 1918 r., red. B. Baranowski, J. Fijałek, Warszawa-Łódź 1980, s. 376.

${ }^{11}$ J. Lukasiewicz, Finanse 1795-1918, [w:] Historia Polski w liczbach, t. 2: Gospodarka, red. A. Jezierski, A. Wyczański, Warszawa 2006, s. 299-300.

${ }^{12}$ „Lodzianin”. Kalendarz informacyjno-adresowy na rok 1894, R. V, 1893, Dział adresowy, s. 12;

K. Stefański, Gmachy użyteczności publicznej dawnej Łodzi, Łódź 2000, s. 14.

${ }^{13} \mathrm{~K}$. Badziak, Instytucje finansowo-kredytowe w Łodzi do I wojny światowej, „Rocznik Łódzki”, t. $22(25), 1977$, s. 82.

${ }^{14}$ APŁ, Łódzki Oddział Banku Państwa, sygn. 34, 37; F. Friedman, Rozwój gospodarczy..., s. 96; K. Badziak, Instytucje finansowo-kredytowe..., s. 82-83. 
The outbreak of WWI and the invasion of German army caused a financial crisis in Łódź after the closure of the branch ${ }^{15}$. In that particular moment, members of discount and loan committee were: Zygmunt Richter, Jakub J. Peters, Karol Eisert, P.W. Schweikert, Henryk Barciński, Karol Hoffrichter, Salomon L. Danziger, Karol Kröning, Juliusz Kindermann and dr Alfred Biedermann ${ }^{16}$.

At the beginning of the $20^{\text {th }}$ century, Russian authorities decided that the local branch of the National Bank relocated to a more representative building. The new office was deigned by Dawid Lande, an acclaimed architect from Łódź. The building on the corner of Spacerowa Street (now 14 Kościuszki Avenue) and Benedykta Street (now 6 Sierpnia Street ${ }^{17}$ ) was finished as late as in 1908 since the construction process got suspended between 1905 and 1907, due to the 1905 Revolution.

On the first floor of that establishment, there was the biggest bank hall in Europe, with its floor area of circa $1150 \mathrm{~m}^{2}$ (the length of the hall was $52 \mathrm{~m}$ ) ${ }^{18}$. The subsequent directors of the Łódź branch of the National Bank were: M. Maszowski (Maszewski) - radca kolegialny (until 1897), A.P. Żółtanowski - radca dworu and A.A. Mołotkow - radca stanu ${ }^{19}$.

At the beginning of WWI, the branch was dissolved and the office got into the hands of German army, becoming its headquarters ${ }^{20}$. Those who kept their money in the premises lived in fear of losing their savings after the escape of the bank employees. On Sptember 25, 1914, in „Nowy Kurier Łódzki” there appeared a notice, claiming that the Warsaw branch of the National Bank would return money to its clients, but only to the value of $60 \%$ of the sum ${ }^{21}$. In December 1914 , in the building of Łódź branch of the National Bank circa 500 Russian soldiers imprisoned after the battle of Łódź were kept ${ }^{22}$.

The rapid industrial development in the Kingdom of Poland, Łódź especially, after 1864, provoked the necessity to set up an independent private credit institution to satisfy the basic needs that were not acknowledged neither by the branch of the Bank of Poland in Łódź from 1858 (in reality from 1860) nor by the later existing National Bank.

${ }^{15}$ „Nowy Kurier Łódzki”, nr 224, 2 IX 1914, s. 1. Por. K. Badziak, Instytucje finansowo-kredytowe..., s. 83.

${ }^{16}$ Informator Handlowo-Przemystowy miasta Łodzi 1914, s. 95.

${ }^{17}$ Changes in the names of streets in: J. Kita, M. Nartonowicz-Kot, Patroni ulic łódzkich, Łódź 2012, ss. 404.

${ }^{18}$ The building of the branch of the Bank of Poland in Łódź at 14 Kościuszki Avenue in Łódź, by: M. Ertman, Łódź 1981 (Wojewódzki Urząd Ochrony Zabytków w Łodzi); K. Stefański, Gmachy użyteczności..., s. 15.

19 „Łodzianin”. Kalendarz informacyjno-adresowy, R. V, 1893, Dział adresowy, s. 12; „Czas”. Kalendarz na rok 1902, Dział adresowy, s. 45c; Informator Handlowo-Przemystowy miasta Łodzi 1914, s. 95.

${ }^{20}$ K. Stefański, Gmachy użyteczności..., s. 16.

${ }^{21}$ „Nowy Kurier Łódzki”, nr 222, 25 IX 1914, s. 2.

22 „Nowy Kurier Łódzki”, nr 286, 9 XII 1914, s. 3. 
Łódź industry was short of money and the need of credit was widely popular. The Bank of Poland was deprived of independence by the Russians so it was not in a position to serve as a „credit bank of efficient multilateral undertaking”"23.

The greatest entrepreneurs of Łódź had no option but to cooperate not only with the financial and credit institutions of Warsaw, but also with banks far from the Kingdom of Poland (from Wrocław, Berlin and London). Thus, in 1871, an idea to found a joint-stock bank with private capital was born. Not to mention the fact that in 1870 there was finally favourable atmosphere to open private jointstock associations. In 1860s in Russian Empire there appeared several joint-stocks Russian banks ${ }^{24}$. The idea of creating such an institution in Łódź came along the entrepreneurs and clerks of the capital of the Kingdom of Poland (Dawid Rosenblum and Ludwik Starkman) ${ }^{25}$. A founding committee of eleven members with Karol Scheibler was born. On August 19, 1872, the name Commercial Bank (Bank Handlowy) was coined. The board of this institution consisted of its two Warsaw inventors - D. Rosenblum and L. Starkman, but also industrialists from Łódź: the Germans - K. Scheibler and Ludwik Grohmann and the Jews: Wilhelm Ginsberg and Herman Konstadt. The first stocks (of $2 \mathrm{mln}$ rb. value) were shared mainly between the local founding fathers, but some of them were distributed to the Warsaw bankers, with Leopold Kronenberg, who in 1873 was in possession of 41,77\% of shares, among others. The fact that the wealthiest man in the whole Kingdom of Poland invested in this enterprise guaranteed its secure position and proved its reliability ${ }^{26}$. The bank was located in a small, yet very posh building at 16 Średnia Street (now 18 Pomorska Street), bought from Karol Gebhardt ${ }^{27}$.

Over time, Łódź capital surpassed that of Warsaw. At the end of the $19^{\text {th }}$ century, the shareholders from Warsaw were in possession of circa $15-20 \%$. The Scheibler-Herbst family, who, due to official Russian legal regulations were not allowed to keep the control block of the Bank, played a decisive role in the Bank activities by creating their own group of loyal shareholders possessing over $50 \%$ of voice in the general assembly.

${ }^{23}$ S. Kempner, Dzieje gospodarcze Polski porozbiorowej, t. 1, Warszawa 1920, s. 97. Trans. by author.

${ }^{24}$ See: A. Żor, Kronenberg. Dzieje fortuny, Warszawa 2011, s. 247, 252-253. Between 1864 and 1869 several commerical banks were established in Russia: Petersburski Prywatny Bank Handlowy (1864), Moskiewski Bank Kupiecki (1866), Kijowski Prywatny Bank Handlowy (1868), Charkowski Bank Handlowy (1868), Bank Dorpacki (1869), a ponadto Bank Handlowy w Warszawie (1870) i Bank Dyskontowy w Warszawie (1871).

${ }^{25}$ I. Schiper, Dzieje handlu żydowskiego na ziemiach polskich, Warszawa 1937, s. 478; S. Kempner, Dzieje gospodarcze..., t. 1, s. 93, 251.

${ }^{26}$ Zob. A. Żor, Kronenberg. Dzieje fortuny...

${ }^{27}$ „Łodzianin”. Kalendarz informacyjno-adresowy, R. V, 1893, Dział adresowy, s. 12; „Czas”. Kalendarz na rok 1902, Dział adresowy, s. 45c. 
Other families allied with them, like the Grohmanns, the Jannaszes, the Schloessers (from Ozorków) and the Werners (from Leśmierz, Puczniew). No sooner than just before the outbreak of WWI had the Scheibler-Herbst family's shares been reduced to $1 / 3$ of the whole stocks of the Bank. It ought to be mentioned that members of the families in question served as the Banks acclaimed officials: K. Scheibler was the Chair of the Board of Directors in the years 1872-1881, and his son-in-law had the same post in 1885-1914.

Their kin, nimi Henryk Wilhelm Schloesser, was also the Chair, working there in the mid-period of 1881-1884. Dr Alfred Biedermann was offered the same post during WWI. Other relatives were the members of the Board in question ${ }^{28}$.

The Board was dominated by industrialists of German origin; apart from those previously spoken of, one should also mention the family of Heinzl, Kunitzer, Richter and Kindermann. The families of Jewish origin paid much less exposed role in the activities of the Bank. Among them there were: the Starkmans, Maks Kernbaum, the Jarocińscy, the Goldfederows, Hugo Wulfsohn, Michał Landie (Lande), Adam Osser, Herman Konstadt ${ }^{29}$. Members of the Council and Board were paid for their work in both collegial bodies. For instance, in 1911 they were granted over 70,5 tys. rb. as payment ${ }^{30}$

Commercial Bank paid a crucial role in the economic life of the developing city, by discounting and bill collecting, offering loans, mediating in obtaining credit from foreign banks, trading of securities, currencies (also foreign), securities collecting and aiding factories and trade companies with the permission of the authorities and on commercial grounds ${ }^{31}$.

Owing to such operations performed, the Bank was the source of income (dividend) for the shareholders, the abovementioned families of industrialists especially.

In 1876, general income from dividend was $20900 \mathrm{rb}$., but in 1913 it was $574000 \mathrm{rb}$. For instance, in 1881, $30 \mathrm{rb}$. per share was paid for $250 \mathrm{rb}$., in 1891 the shareholders received $25 \mathrm{rb}$. per share for $250 \mathrm{rb} .{ }^{32}$ The dividend in 1908 equaled $22 \mathrm{rb} .50 \mathrm{kop}$. per share for $250 \mathrm{rb} .{ }^{33}$

28 Sprawozdania Banku Handlowego w Eodzi za lata 1872/1873-1918, Warszawa-Lódź 1874-1919. For instance, in 1914 the vice-presidents of the Board were Karol Scheibler jr. and dr Alfred Biedermann, and the Board members were: Teodor Ender, Henryk Grohmann, Henryk Herbst (Warsaw), Jakub Hirschberg, Juliusz Kindermann, Edward Landie (Warsaw), Jakub Peters, Józef Richter, Ryszard Steinert. Informator Handlowo-Przemysłowy miasta Lodzi 1914, s. 96.

${ }^{29}$ Sprawozdania Banku Handlowego w Lodzi za lata 1872/1873 - 1913, Warszawa 1874-1914; „Czas”. Kalendarz na rok 1902, 1909, 1911; Żydzi w Polsce Odrodzonej: działalność społeczna, gospodarcza, oświatowa i kulturalna, pod red. I. Schipera, A. Tartakowera, A. Haftki, t. 2, Warszawa 1933, s. 452.

${ }^{30}$ Sprawozdanie Banku Handlowego w Łodzi za rok 1911, Warszawa 1912.

${ }^{31}$ „Czas”. Kalendarz na rok 1909, s. 8p.; „Czas”. Kalendarz na rok 1911, s. 5 p.

${ }^{32}$ Sprawozdanie Banku Handlowego w Łodzi za rok 1881, Warszawa 1882; , Łodzianin”. Kalendarz informacyjno-adresowy, R. V, 1893, s. 179.

${ }^{33}$ „Kurier Łódzki”, nr 140, 23 IV 1909 r. 
The volume of trade speeded. In the years 1872/73 it equaled the sum of 47,3 mln rb., in 1881 it exceeded $100 \mathrm{mln}$ rb. (107,2 mln rb.), ten years later, in 1891 $-172,5 \mathrm{mln} \mathrm{rb}$, whereas in 1899 it reached and enormous sum of 1,136 mld rb. The income of the Bank in 1891 was 187749 rb. 83 kop., while in 1907 it rose to 495187 rb. 5 kop., and in 1911 it was over one million rb. (1 009606 rb. 30 kop.) $)^{34}$. Capital stock increased: In 1903 it was $5 \mathrm{mln}$ rb., a in $1911-10 \mathrm{mln} \mathrm{rb}$. and reserve capital in 1903 equaled 2,5 mln rb., while in $1911-5,5 \mathrm{mln} \mathrm{rb} .(0,5 \mathrm{mln} \mathrm{rb}$. reserve social fund included). Reserve fund consisted of ,national papers approved of by the authorities" ${ }^{\prime 3}$. Commercial Bank in Łódź was the second wealthiest financial institution of this kind in the Kingdom of Poland after the Commercial Bank in Warsaw (with circa $30 \mathrm{mln} \mathrm{rb}$.). It belonged to the second rank of private banks in Russian Empire, among 38 of the same kind, with stock capital of 5-10 mln rb. The Bank shares went debuted in the stock - first in Petersburg and Warsaw, and later $\mathrm{n}$ Łódź.

In the late $19^{\text {th }}$ century, the Bank made effort to expand its activities outside Łódź and thus opened branches: first in Warsaw (in 1897) at 6 Erywańska Street and later in Lublin, Radom, Kielce (provincial branches), and Chełm, Ostrowiec, Zamość (agencies) ${ }^{36}$. In 1911 impressive business trade of the branches (1 $228755892 \mathrm{rb}$. 78 kop.) surpassed the one of the head office in Łódź (1 025972183 rb. 58 kop.) . $^{37}$.

During prosperity times, having defeated the difficulties connected with the revolution of 1905, a decision to erect a representative headquarters of the Bank was made. The new building was constructed at 15 Spacerowa Street 15 (now Kościuszki) ${ }^{38}$, opposite the office of the National Bank. It was designed by the employers of most famous building company „Bielenberg und Moser” which specialized in bank building designs. The new office, proving the Bank's top position in the financial sphere of the town, was erected in the years 1911-1913. It was the second prestigious public office in Łódź, just after the property of the National Bank. Both buildings were meant to bring up the ideals of an honest financial institution: reliability, continuity and wealth. Today, the office of the Commercial Bank hosts PKO Bank Państwowy (I Oddział) ${ }^{39}$. Subsequent directors of the

\footnotetext{
${ }^{34}$ Sprawozdanie Banku Handlowego w Lodzi za rok 1888, Warszawa 1889; za rok 1891, Warszawa 1892; za rok 1903, Warszawa 1904; za rok 1907, Warszawa 1908; za rok 1911, Warszawa 1912; „, Łodzianin”. Kalendarz informacyjno-adresowy, R. V, 1893, s. 179.

${ }^{35}$ Sprawozdania Banku Handlowego w Lodzi za lata 1872/1873-1913, Warszawa 1874-1914. Trans. By author.

${ }^{36}$ „Czas”. Kalendarz na rok 1909, s. 8 p.; „Kurier Łódzki”, nr 140, 23 IV 1909 r.

${ }^{37}$ Sprawozdanie Banku Handlowego w Lodzi za rok 1911, Warszawa 1912.

${ }^{38}$ Informator Handlowo-Przemystowy miasta Lodzi 1914, s. 96.

${ }^{39}$ Budynek Banku Handlowego w Łodzi, al. Kościuszki 15, oprac. M. Ertman, Łódź 1980 (Wojewódzki Urząd Ochrony Zabytków w Łodzi).
} 
Commercial Bank were: Reinhold Neumann (until 1887), Moritz (Maurycy) Tauber and Izydor Zand ${ }^{40}$.

During WWI, Commercial Bank in Łódź was in crisis and suffered loss in its capital (during 1914-1915 circa 3,2 mln rb.), since Russian government stock, treasury bonds of railway companies and shares of firms lost their value ${ }^{41}$. At the outbreak of WWI, in Commercial Bank (Bank Handlowy), the citizens were distributed stock issue confirmations and cash certificates in exchange of money deposit ${ }^{42}$. The certificates were signed by Jakub Peters and Izydor Zand on behalf of the Bank. It was not until 1918 that business trade of Bank increased (circa $750 \mathrm{mln} \mathrm{rb}$.), which was definitely due to the activities of the branches (over 560 $\mathrm{m} \ln \mathrm{rb}.)^{43}$.

A dynamic development of industry in Łódź in 1890s led to capital gathering, which spurred local industrialists to seek new possibilities of investment. Thus, there was an opportunity for industrialists of the Geyer family (Emil, Eugeniusz, Ryszard), Oskar Kindler, and Leopold Landau to open a new private bank in Łódź in 1897.

The establishment of Merchant Bank (Bank Kupiecki) in Łódź was approved of on January 2, 1897. Its activities were very similar to those of Commercial Bank. First, the office was located in a magnificent tenement house at 1 Spacerowa Street (now Kościuszki) ${ }^{44}$, but in 1904 it was moved to a building originally erected for Ludwik Geyer (1886) at the corner of 74 Piotrkowska Street and Meyera Arcade, a highly prestigious area ${ }^{45}$. Łódź press acknowledged setting up a new financial and credit institution, claiming that "a solid business needs proper entourage".

Merchant Bank was created on the basis of Jewish bank houses of Warsaw of Szymon Neuman and Dawid Maliniak and a Łódź bank house of Leopold Lan$\mathrm{dau}^{46}$. The Bank was governed by Board of Directors, with its two Chairs - Emil Geyer and Leopold Landau, and with its President Eugeniusz Geyer. The relatives of the Geyers and the Landaus were members of the Board and Management ${ }^{47}$.

${ }^{40}$ Sprawozdania Banku Handlowego w Łodzi za lata 1872/1873 - 1913, Warszawa 1874-1914; „Czas”. Kalendarz na rok 1902, Dział adresowy, s. 45c; Informator Handlowo-Przemystowy miasta Eodzi 1914, s. 96.

${ }^{41}$ Sprawozdanie Banku Handlowego w Lodzi za lata 1914/1915, Łódź 1916.

${ }^{42}$ „Nowy Kurier Łódzki”, nr 192, 24 VIII 1914, s. 3.

${ }^{43}$ Sprawozdanie Banku Handlowego w Lodzi za rok 1918, Łódź 1919.

${ }_{44}^{44}$ „Czas”. Kalendarz na rok 1902, Dział adresowy, s. 45c.

${ }^{45}$ Informator Handlowo-Przemystowy miasta Łodzi 1914, s. 96.

${ }^{46}$ Żydzi w Polsce Odrodzonej..., t. 2, s. 451; I. Schipper, Dzieje handlu żydowskiego ..., s. 519.

${ }^{47}$ For instance, in 1914 Ernest Leonhardt became the Chair of the Board of Directors, and the members of the Board were: Ernest Wever, Borys Wachs, Maks Kernbaum, Alfred Landau, Zenon Kon (Bank Director). Natomiast Management Board consisted of: Leopold Landu (President), Reinhardt Bennich, Maks Fischer, Oskar Kindler, Szymon Neuman, Paweł Górski. Informator HandlowoPrzemystowy miasta Łodzi 1914, s. 96. 
The majority of shares were in the hands of the abovementioned families, but also people representing industry, other banks and trading firms (the Weils, the Kindlers, the Dobraniecki, the Meyerhoffs). The initial capital stock equaled $2 \mathrm{mln} \mathrm{rb}$., but in the subsequent years it rose by emitting shares. In 1899 it comprised $3 \mathrm{mln} \mathrm{rb}$., and in $1910-5 \mathrm{mln} \mathrm{rb}{ }^{48}$

After 1904, having its financial basis secured, Merchant Bank began crediting industry to a greater extent than Commercial Bank. It supported the businesses of its key shareholders. With time, a large part of the Bank's stock was purchased by Russian banks (mainly from Petesburg) due to Leopold Landau, who was the first rank merchant in Petersburg ${ }^{49}$. At the beginning of the $20^{\text {th }}$ century, the stock of Merchant Bank debuted in the Warsaw stock market, but they were not considered highly valuable. Trying to enlarge the area of its activities, Merchant Bank opened a branch in Odessa, but it was soon closed due to insufficient income. On the contrary, its Warsaw branch, founded in 1911 and located at 9 Wierzbowa Street ${ }^{50}$, proved to be extremely successful and as soon as in 1913 it offered business trade value which was higher than that of the head office. It should be mentioned, however, that until the outbreak of WWI, Merchant Bank was still in search of clients and areas of activity, which made its business trade value still lower than that of Commercial Bank, which had already had a steady position. The Directors of Merchant Bank were Z. Einbild and Zenon Kon ${ }^{51}$.

Since August 1914, Merchant Bank, similarly to Commercial Bank, distributed stock issue confirmations and cash certificates in exchange of proper deposit.

The Bank agreed on promissory notes with signatures of acceptance of other banks, and shares, but also precious objects, like jewellery or gold of a value that would double the certificates received in exchange. The certificates were signed by Ernest Vewer i Zenon Kon on behalf of the Merchant Bank.

One more area of Łódź banks activity should be mentioned. Similarly to Warsaw Commercial Bank (Bank Handlowy), they cooperated with foreign, especially Western European financial institutions. Secondary sources describing that process highlighted its negative sides, claiming that the banks heavily depended on their foreign partners, like German Deutsche Bank (Berlin) or Dresdner Bank, thus relying on foreign capital ${ }^{52}$. Nowadays such interpretation is not valued, since at the turn of the $20^{\text {th }}$ and $20^{1 \text { st }}$ centuries such economic contacts are considered standard.

\footnotetext{
${ }^{48}$ K. Badziak, Instytucje finansowo-kredytowe..., s. 92-94; S. Pytlas, Łódzka burżuazja przemysłowa w latach 1864-1914, Łódź 1994, s. 109-111.

${ }^{49}$ Zob.: S. Pytlas, Łódzka burżuazja..., tab. 16, s. 110.

${ }^{50}$ Informator Handlowo-Przemystowy miasta Łodzi 1914, s. 96.

${ }^{51}$ „Czas”. Kalendarz na rok 1902, Dział adresowy, s. 45c; „Czas”. Kalendarz na rok 1911, s. 19c; Informator Handlowo-Przemystowy miasta Łodzi 1914, s. 96.

${ }_{52}$ In: I. Pietrzak-Pawłowska, Królestwo Polskie w początkach imperializmu 1900-1905, Warszawa 1955, s. 210-211.
} 
Banks od Łódź mediated in the contacts with powerful German and English financial institutions, enabling local industrialists to import materials and machinery due to long and short-term credits. Foreign bank credits were being paid off and neither big factories of such prominent figures as K. Scheibler and I.K. Poznański among many others, nor the banks of Łódź were indebted to foreign banks ${ }^{53}$.

Since Łódź, a huge industrial city, was rapidly developing, a branch of Russian National Bank and two private stock banks were not in a position to satisfy the financial needs of the locals. This is precisely why other financial organizations, like Russian (especially the Petersburg) banks and Warsaw Commercial Bank, decided to establish their branches here. In 1893 there appeared a branch of AzowDońsk Commercial Bank (Azowsko-Doński Bank Handlowy) in Łódźn ${ }^{54}$. At the beginning, its office was in rented buildings, at 71 Piotrkowskiej Street, and from 1902 in a property at 8 Meyera Arcade (now Traugutta) ${ }^{55}$. Bruno Köhler was the Director of the branch, Hipolit Wolberg, J. Tuwin, Henryk Krukowski, K. Schmidt, among many others, were authorized clerks ${ }^{56}$. At the beginning of August, 1914, the branch closed.

The branch of Warsaw Commercial Bank opened in Łódź in 1896, and, after several relocations ${ }^{57}$, it moved to a tenement house at 17 Dzielna Street (now Narutowicza) $)^{58}$. Industrialists and merchants of Łódź had long been cooperating with this institution, but its business trade value dramatically rose, which proves its great popularity among them. This institution focused mainly on giving credits to enterprises of Łódź, for instance that belonging to K. Scheibler and I.K. Poznański, and on purchasing real estates. The Directors of the branch were L. Reinecke and Zygmunt Weinreb (Weinreib) ${ }^{59}$. The outbreak of WWI made the bank activities difficult to continue and the local branch of the Warsaw Commercial Bank was no exception. In mid-August 1914, 80 employees of the branch

${ }^{53}$ W. Puś, Przemyst włókienniczy w Królestwie Polskim w latach 1870-1900. Zagadnienia struktury i dynamiki rozwoju, Łódź 1976, s. 28; tenże, Rozwój przemystu ..., s. 34. Por. I. Ihnatowicz, Przemyst tódzki 1860-1900, Wrocław 1965, s. 120; Z. Landau, J. Tomaszewski, Kapitaly obce w Polsce 1918-1939. Materiaty i dokumenty, Warszawa 1964, s. 16.

${ }^{54}$ This Bank was established in Russia in 1871.

55 „Łodzianin”. Kalendarz informacyjno-adresowy, R. V, 1893, s. 12; Informator Handlowo-Przemystowy miasta Łodzi 1914, s. 97.

${ }^{56}$ „Czas”. Kalendarz na rok 1902, Dział adresowy, s. 45c; „Czas”. Kalendarz na rok 1909, Dział adresowy, s. 17; Informator Handlowo-Przemystowy miasta Łodzi 1914, s. 97.

${ }^{57}$ In 1896, the main office of the Banku was located in the tenement house of Abel - at 11 Południowa Street (now Rewolucji 1905 Street), later it was moved to 5. Mikołajewskiej Street (now. Sienkiewicza). „Czas”. Kalendarz na rok 1902, Dział adresowy, s. 45c.

${ }^{58}$ Informator Handlowo-Przemystowy miasta Lodzi 1914, s. 96.

59 „Czas”. Kalendarz na rok 1902, Dział adresowy, s. 45c; „Czas”. Kalendarz na rok 1909, Dział adresowy, s. 17; Informator Handlowo-Przemystowy miasta Łodzi 1914, s. 96. 
were paid three months salary in advance, but they were also warned that in case of war lasting longer, further payment would be halted ${ }^{60}$.

One year later, in 1897, a branch of yet another Russian bank, Ryga Commercial Bank (Ryski Bank Handlowy) was established in Łódź. Its locations were tenement houses, first at 5 Zielona Street, later 64 Zachodnia Street ${ }^{61}$, and in 1911 the bank bought a tenement house at 57 Piotrkowska Street, to set its head office there ${ }^{62}$. The branch of Ryga Commercial Bank finansed for instance the purchase of textile raw materials, paints and chemicals.

The directors of the branch were: P. Pinkas, Adam Becker i Stanisław $\mathrm{Kroll}^{63}$. At the dawn of WWI, the branch was closed in fear of the German army approaching.

The last to appear in Łódź was the branch of Wołżsko-Kamski Commercial Bank (Wołżsko-Kamski Bank Handlowy) that appeared in $1906^{64}$, and found a perfect location at 4 Meyera Arcade. Until WWI, the branch directors were Józef Karpowicz and Franciszek Zachert ${ }^{65}$. On August 18, 1914 rthe branch was closed, and all its clerks with documents, archives and stock moved to Petersburg, where all clients were requested to $\mathrm{ply}^{66}$. In November 1914 the breathtaking office was used by colonel von Baumgarten ${ }^{67}$.

The abovementioned banks served mainly the wealthiest industrialists with their aid, whereas humbler companies of craft and trade relied mostly on local bank houses and branches of Warsaw institutions of the kind, which were in the hand of the Jews. The number of such associations was not impressive: there was only one of them in 1870, 11 in the years 1902-1904, and 3 in $1913^{68}$.

The most prominent institution of the kind was the branch of Warsaw bank house of Wilhelm Landau, a most famous Jewish financier ${ }^{69}$. It was the oldest privately owned bank company in Łódź with still growing business trade value since

\footnotetext{
${ }^{60}$ „Nowy Kurier Łódzki. Dodatek Nadzwyczajny”, 16 VIII 1914 r., s. 2.

${ }^{61}$ „Czas”. Kalendarz na rok 1902, Dział adresowy, s. 45c.

${ }^{62}$ In 1914 the old address: 64 Zachodnia Street was still given as the Bank headquarters. Informator Handlowo-Przemysłowy miasta Łodzi 1914, s. 97.

${ }^{63}$ „Czas”. Kalendarz na rok 1902, Dział adresowy, s. 45c; Informator Handlowo-Przemystowy miasta Łodzi 1914, s. 97.

${ }^{64}$ Wołżsko-Kamski Bank powstał w Rosji w 1870 r.

${ }^{65}$ „Czas”. Kalendarz na rok 1909, Dział adresowy, s. 17; Informator Handlowo-Przemystowy miasta Łodzi 1914, s. 97.

${ }^{66}$ „Nowy Kurier Łódzki”, nr 187, 19 VIII 1914, s. 2.

${ }^{67}$ „Nowy Kurier Łódzki”, wydanie poranne, 27 XI 1914, s. 1.

${ }^{68}$ „Czas”. Kalendarz na rok 1900, 1902, 1904, 1909, 1911, 1913; „, Lodzianin”. Kalendarz informacyjno-adresowy na rok 1894, Łódź 1893, Dział adresowy, s. 12; Führer durch Lodz, Lodz 1898, Allgemeine Adressen, s. 6-7.

${ }^{69}$ Established in Warsaw in 1857, in the cooperation with Ludwik Landau. Żydzi w Polsce Odrodzonej..., t. 2, s. 449.
} 
its founding in $1870^{70}$. In 1902 the value of the branch reached over 3,3 mln $\mathrm{rb}$. Initially, the office was located in a tenement house at 39 Piotrkowska Street $^{71}$, but huge income and permanent stays triggered the entrepreneur to invest in real estates and find a proper residence in Łódź.

In the years 1902-1903, a new posh office, designed by most famous architect, Gustaw Landau-Gutenteger, was erected at the corner of 29 Piotrkowskiej Street and Ceglana Street (now Więckowskiego). It was considered to be one of the most spectacular buildings at Piotrkowska Street. On the ground floor, there were luxurious stores located, on the first floor there were bank offices, whereas on the two top floors there were comfortable spacious flats ${ }^{72}$. In 1913 the company was transformed into a joint-stock bank, with a capital of $5 \mathrm{mln} \mathrm{rb}$. Unfortunately, the beginning of WWI disabled the bank to develop further both in Łódź and in Warsaw ${ }^{73}$.

Among other bank houses and their branches there was one more institution of the kind worth mentioning. It was the one that belonged to Adolf Goldfeder, founded in Warsaw in 1860. Its Łódź branch was the main rival of the bank house of L. Landau with its business trade value of $2 \mathrm{mln}$ rb in 1898. The Łódź branch was governed by the brother of its owner, Łódzką Maksymilian Goldfeder ${ }^{74}$. In 1892 the men erected a magnificent house at 77 Piotrkowska Street in Łódź. On the ground floor there were the offices of bank house, and on the floors there were beautifully ornamented and furnished flats ${ }^{75}$.

As has been mentioned, other financial and credit institutions that paid an important role in Łódź ${ }^{76}$ have been omitted in the paper. One of them was Towarzystwo Kredytowe Miejskie, founded in 1872, located at 21 Średniej Street (now Pomorska) and mutual credit companies of mutual credit and savings and loan companies $^{77}$.

The outbreak of WWI meant crisis of banks and other financial and credit institutions; the branch of the National Bank and local branches of the Russian banks disappeared. Their employees did not receive salary and could not have been given stable posts. Evidence of the situation can be traced in Łódź press of the period ${ }^{78}$.

\footnotetext{
${ }^{70} \dot{Z} y d z i$ w Polsce Odrodzonej..., t. 2, s. 449.

${ }^{71}$ „Łodzianin”. Kalendarz informacyjno-adresowy, R. V, 1893, s. 12; „Czas”. Kalendarz na rok 1902, Dział adresowy, s. 46c.

${ }^{72}$ House of the banking company W. Landau w Lodzi, ul. Piotrkowska 29, oprac. M. Ertman, Łódź 1984 (Wojewódzki Urząd Ochrony Zabytków w Łodzi).

${ }^{73}$ Żydzi w Polsce Odrodzonej ..., t. 2, s. 449.

${ }^{74}$ Tamże, t. 2, s. 449-450.

${ }^{75}$ „,Lodzianin”. Kalendarz informacyjno-adresowy, R. V, 1893, s. 12; „Czas”. Kalendarz na rok 1902, Dział adresowy, s. 46c.

${ }^{76}$ In K. Badziak, Instytucje finansowo-kredytowe..., s. 97-106; S. Pytlas, Łódzka burżuazja..., s. $105-117$.

${ }^{77}$ In A. Bardzki, Towarzystwa kredytowe miejskie, cz. 1: Powstanie i rozwój, Warszawa 1912, rozdział II.

${ }^{78}$ „Nowy Kurier Łódzki”, nr 195, 27 VIII 1914, s. 2; nr 200, 2 IX 1914, s. 2.
} 
To sum up, it should be stressed that in the second half of the $19^{\text {th }}$ century and at the beginning of the $20^{\text {th }}$, there was a continuous and stable development of the activities of banks and bank houses in Łódź. Despite some short periods of stagnation, which were caused by global crises, business trade value kept increasing. Until the outbreak of WWI, Łódź was the second centre of banks and financial and credit institutions in the whole Kingdom of Poland, just after Warsaw. Nevertheless, the ability to obtain a short or long-term credit was insufficient. It was not merely the inability to serve of the institutions in question, but rather the restrictions imposed by the foreign authorities who treated the area of the Kingdom of Poland as inferior. Russian economic policy impeded the activities of jointstock banks in Łódź, whereas the National Bank (Bank Państwa) and branches of the Russian banks focused on obtaining stock and gaining income for their head offices and Russian Empire Treasury.

Jarosław Kita

\section{BANKI ŁÓDZKIE I ICH DZIAŁALNOŚĆ DO 1918 ROKU}

Stereotyp XIX-wiecznej Łodzi to wizerunek miasta potężnych fabryk, przede wszystkim włókienniczych, kipiących przepychem pałaców i willi fabrykanckich, uzupełniony o mit Łodzi secesyjnej. W takim mieście rządził przede wszystkim pieniądz i zysk. Miasto przemysłowe, w którym obracanie kapitałem i gromadzenie coraz większych zysków odgrywało tak doniosłą rolę, nie mogło funkcjonować bez wszelkiego rodzaju instytucji finansowo-kredytowych z bankami na czele, ułatwiającymi obrót pieniądza oraz pozyskiwanie kredytów i pożyczek. Jednak przez kilka dziesięcioleci przemysłowego rozwoju w mieście nie istniał żaden bank, ani żadna inna instytucja finansowo-kredytowa. Sytuacja zmieniła się dopiero w przededniu wybuchu powstania styczniowego. Przez następne pół wieku, do wybuchu I wojny światowej, w wyniku intensywnego rozwoju gospodarczego Łodzi oraz okolicznych miast i miejscowości, powstało tutaj szereg nowoczesnych instytucji finansowych. Kiedy w 1870 r. w Łodzi było tylko 2 tego typu instytucje, to w 1913 r., w przestrzeni miasta funkcjonowało już 37 instytucji finansowo-kredytowych.

W okresie odwilży posewastopolskiej, w 1858 r., podjęto decyzję o powołaniu do życia w Łodzi oddziału Banku Polskiego, którego naczelnym zadaniem było przede wszystkim wspieranie polityki gospodarczej rządu Królestwa Polskiego. Uzyskanie kredytu długoterminowego przez miejscowych przemysłowców było wyraźnie utrudnione. Niebawem łódzka filia Banku Polskiego przekształcona została w kantor rosyjskiego Banku Państwa. Stąd też w 1871 r. pojawiła się idea utworzenia w Łodzi banku akcyjnego z kapitałem prywatnym. 19 VIII 1872 r. zatwierdzono ustawę Banku Handlowego w Łodzi, a do władz nowo powołanej instytucji weszli obok warszawskich pomysłodawców, łódzcy przemysłowcy: niemieccy - K. Scheibler i L. Grohman oraz żydowscy - W. Ginsberg i H. Konstadt. Z czasem decydująca rolę odgrywała w nim rodzina Scheiblerów-Herbstów. Przez niemal cały okres w zarządzie Banku Handlowego dominowali przemysłowcy pochodzenia niemieckiego. Łódzki Bank Handlowy pod względem zasobności w przestrzeni Królestwa Polskiego ustępował wówczas jedynie Bankowi Handlowemu w Warszawie. 
Dynamiczny rozwój łódzkiego przemysłu w latach 90. XIX w. prowadził do nagromadzenia kapitałów, a to skłaniało miejscowych przemysłowców do szukania okazji ich korzystnej lokaty. Stąd też czas na kolejny łódzki bank prywatny, który powstał w 1897 r. z inicjatywy przemysłowców łódzkich z rodziny Geyerów, a ponadto O. Kindlera i L. Landaua. Jego sfera działalności nie odbiegała od form działalności Banku Handlowego.

W przestrzeni dynamicznie rozwijającego się wielkiego przemysłowego miasta oddział rosyjskiego Banku Państwa oraz dwa prywatne banki akcyjne nie mogły zaspokoić miejscowych potrzeb finansowo-kredytowych. Stąd też na rynku łódzkim swojej szansy na poważne zyski poszukiwały banki rosyjskie oraz warszawski Bank Handlowy, które z czasem założyły tutaj swoje oddziały: Azowsko-Doński Bank Handlowy (1893), warszawski Bank Handlowy (1896), Ryski Bank Handlowy (1897), Wołżsko-Kamski Bank Handlowy (1906).

Powyższe banki związane były swoimi interesami przede wszystkim z największymi przemysłowcami Łodzi i okręgu, natomiast w obsłudze mniejszych zakładów, rzemiosła i handlu specjalizowały się raczej domy bankierskie. Ich właściciele wywodzili się ze środowiska żydowskiego, a liczba tych instytucji finansowo-kredytowych w Łodzi wahała się od $1 \mathrm{w} 1870$ r. przez 11 w latach 1902-1904, do 3 w 1913 r.

Do wybuchu I wojny światowej Łódź była drugim po Warszawie centrum instytucji bankowych i finansowo-kredytowych w przestrzeni Królestwa Polskiego. Banki łódzkie i inne instytucje o charakterze finansowo-kredytowym wraz z wybuchem I wojny światowej weszły w okres kryzysu, a oddział Banku Państwa i oddziały banków rosyjskich w Łodzi uległy wręcz likwidacji. Wszystkie banki i domy bankowe posiadały w Łodzi piękne siedziby, które do dzisiaj należą do najważniejszych zabytkowych budynków miasta. 